\title{
DEVELOPMENT OF COMBINATORIAL BACTERIA FOR METAL AND RADIONUCLIDE BIOREMEDIATION
}

\author{
A. C. Matin, P.I. \\ Stanford University \\ Grant No. ER63627-1021953-0009581 \\ Final Technical Report \\ Reporting period: 09/15/2003-06/15/2006
}

The grant concerned chromate [Cr(VI)] bioremediation and it was our aim from the outset to construct individual bacterial strains capable of improved bioremediation of multiple pollutants and to identify the enzymes suited to this end. Bacteria with superior capacity to remediate multiple pollutants can be an asset for the cleanup of DOE sites as they contain mixed waste. I describe below the progress made during the period of the current grant, providing appropriate context.

1. Chromate toxicity. Reduction of chromate is toxic to bacteria, as is illustrated in Fig. 1 [1,2] for P. putida and E. coli: their growth is markedly inhibited and the cells acquire abnormal shapes. The external accumulation shown in $P$. putida cell (top right) have also been reported in Caulobacter crescentus grown in the presence of uranyl [3].

2. Soluble "chromate reductases". Some bacteria might be able to respire chromate for energy generation. This has been suggested for Enterobacter cloacae and might be true of others [4]. The electron transport chains of iron and sulfate reducing bacteria can also reduce chromate and other metals and radionuclides but no energy is evidently derived from many of these processes $[5,6]$.

We found that all of some twelve different bacteria we tested reduced chromate using soluble enzymes [1]. These included species of Pseudomonas, Shewanella, Deinococcus and Bacillus. P. fluorescens, S. oneidensis, D. radiodurans and Vibrio harveyi were among the most active (114 - 193 nmol chromate converted/mg cell protein/h). Soluble enzymes for chromate reduction have the potential advantage in that the locus for reduction is intracellular which may promote immobilization and minimize re-oxidation of the reduced species.

3. Soluble one-electron chromate reducers. Why is $\mathrm{Cr}(\mathrm{IV})$ toxic to bacteria? Several metabolic enzymes of the cell, such as lipoyl dehydrogenase, glutathione and cytochrome $b_{5}$ reductases, with the physiological role of energy generation and biosynthesis, can vicariously reduce chromate. Using electron spin resonance (ESR), Shi \& Dalal [7] showed that such enzymes reduce chromate by one electron reduction, generating $\mathrm{Cr}(\mathrm{V})$. This is a highly reactive radical, and rapidly transfers its electron to molecular oxygen or, depending on the conditions to another molecule, generating reactive oxygen species (ROS) or other equally destructive oxidizing agents. Continual activity of the one electron reducers causes $\mathrm{Cr}(\mathrm{VI})$ to shuttle back and forth between the VI and V valence states, generating little net reduced $\mathrm{Cr}$ but large amounts of ROS; this drains the cell's reducing power, and damages its macromolecules through oxidation.

We tested this hypothesis in vitro using pure lipoyl dehydrogenase by our 'redox balance' method. This quantifies the portion of electrons donated by the reductant (NADH) to chromate and to

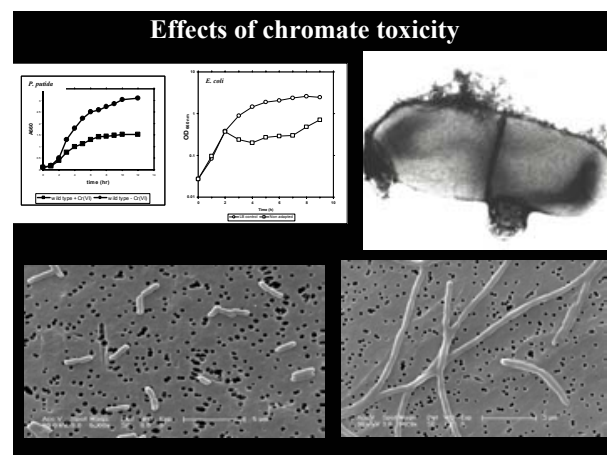

Figure 1. Growth inhibition and morphological changes (right images) generated by chromate. dioxygen). While only $24 \%$ of the electrons were consumed in reducing chromate, over $70 \%$ were used in ROS generation [8, 9]. That chromate reduction by this enzyme involves extensive redox cycling is thus confirmed..

4. In vivo effects of chromate reduction. Thus, certain bacterial enzymes can generate large amounts of ROS from chromate, producing little net conversion of $\mathrm{Cr}$ (VI) to $\mathrm{CR}$ (III). But does this in fact happen inside the cell? To test this we used the dye 2', 7'-dihydrodichlorofluorescein ( $\left.\mathrm{H}_{2} \mathrm{DCFDA}\right)$, which is taken up by the cells and emits green fluorescence in the presence of ROS. The results (Fig. 2) [2] confirmed that cells experienced oxidative stress during chromate reduction. Further 
indications of in vivo oxidative stress by chromate are: a) Cellular free thiols and glutathione levels decline; proteins involved in replenishing the thiol pools (CysN, CysK, sulfate adenylyl transferase) are upregulated, as is SodB that decomposes $\mathrm{O}^{-}$[10-12]. b) Mutants strains missing the individual antioxidant defense genes, $c y s K$, $\operatorname{sod} B, k a t E$ and yieF, showed greater sensitivity to chromate than the wild type. And c) the sfiA gene which is signature gene for the induction of the SOS response due to oxidative-stress is induced. Temporal analysis showed that the up-regulation of these proteins coincided with partial recovery of the cells from chromate stress (decreased $\mathrm{H}_{2}$ DCFDA fluorescence; return to more normal cell morphology) [2].

Oxidative stress is of course only a part of chromate stress. Cr(III), the desirable product of chromate reduction for bioremediation, is itself toxic [13]. However, from the perspective of using bacteria in remediating chromate, the difference between ROS and $\operatorname{Cr}(\mathrm{III})$ toxicity is critical. The former damages bacteria before they have had the chance to carry out the desired reaction; the latter does so after, and there may be a significant chance that a dead bacterium with $\mathrm{Cr}$ (III) complexed within it affords

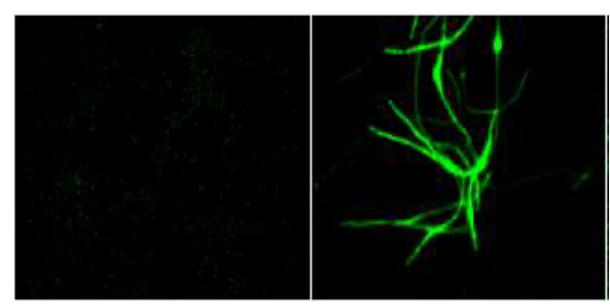

Figure 2. Chromate engendered oxidative stress makes the dye fluoresce (right panel) a means of immobilization. Thus, it would appear that minimizing chromate-mediated oxidative stress is critical for improving bacterial bioremediation capacity.

5. Obligate two-electron reducers. How can oxidative stress engendered by chromate be minimized? Guidance on this came from studies in mammalian cells. They contain an enzyme, called DT diaphorase (NQO1), which is an obligatory twoelectron reducer of its substrates. We hypothesized that if bacteria possessed a functional homologue of this enzyme then that enzyme could, as dimer, reduce chromate in one step. This would bypass $\mathrm{Cr}(\mathrm{V})$ generation, avoid redox cycling and generate $\mathrm{Cr}$ (III) with minimal ROS generation. Such a bacterial enzyme if made more active would outcompete the cellular one-electron chromate reducers and minimize chromate toxicity to the remediating bacteria.

Using a variety of approaches, we succeeded in purifying to homogeneity one such enzyme (ChrR) from P. putida [14]. Analyses showed that several bacteria possessed its sequence orthologues ( $\sim 30 \%$, amino acid identity), but no function assignment had been made to any of these proteins [15]. We have cloned the genes and extensively characterized two bacterial enzymes of this class, ChrR and YieF, as well as an unrelated enzyme (sequence-wise), NfsA, which has been extensively studied [16] but its capacity for obligatory two-electron reduction of chromate was not known prior to our work [9, 15]. Of these YieF was found to be the most tight obligatory two-electron chromate reducer with the widest substrate range, and was therefore chosen for further study.

That YieF reduces chromate without involving redox cycling was confirmed using multiple experimental approaches. The redox balance method showed that only $25 \%$ of the electrons donated by NADH were consumed in ROS generation, the rest being utilized in chromate reduction. Thus, the fourelectron reduced YieF dimer catalyzed a one-step three electron reduction of $\mathrm{Cr}(\mathrm{VI})$ to $\mathrm{Cr}(\mathrm{III})$, with the remaining electron simultaneously reacting with dioxygen to generate ROS, bypassing $\mathrm{Cr}(\mathrm{V})$ generation and redox cycling. That $\mathrm{Cr}(\mathrm{V})$ generation in fact did not occur was confirmed by rapid scan spectrophotometry that makes it possible to detect enzyme redox status at millisecond time scale. No flavin semiquinone enzyme form was detected, indicating absence of a one-electron transfer event [8]. Electron spin resonance measurements which permit direct detection of $\mathrm{Cr}(\mathrm{V})$ conducted with a related enzyme were consistent with these results [9]. Redox balance method indicates that YieF and its evolved enzymes reduce uranyl as well without redox cycling [17].

6. A strategy to mitigate chromate toxicity. Thus bacteria posses "safe" obligatory two electron reducers, and yet chromate generates oxidative stress (Section 4). Clearly the cellular one-electron reducers are more active than the safe enzymes. Would then overproduction in the cell of an enzyme of the safe type mitigate chromate toxicity? The answer is yes: when chromate reduction efficiency per unit growth between the wild type $P$. putida, a mutant missing $\mathrm{ChrR}$, and a strain overproducing this protein 
was tested, the mutant showed decreased, and the over-producer increased efficiency of chromate reduction per unit biomass [9].

A strategy therefore presented itself for minimizing chromate toxicity to bacteria and improving their chromate remediation capability: Improve the kinetics of a safe enzyme for chromate reduction. We reasoned that a significantly active enzyme containing an appropriately high $\mathrm{K}_{\text {cat }} / \mathrm{K}_{\mathrm{m}}$ would be able to sufficiently circumvent channeling of chromate in vivo into the unsafe pathways of one-electron reduction, thereby enabling bacteria to be more resilient in intracellular chromate reduction. This strategy is illustrated in Fig. 3. Indeed, this strategy should improve dissimilatory metal reduction as well, since these bacteria too are subject to oxidative stress by the mechanism described above.

Our studies with uranyl are less extensive so far. But all preliminary indications suggest a situation similar to $\mathrm{Cr}$ : aerobic reduction by cells; redox cycling by one-electron reducers; and "safe" reduction by obligatory two-electron reducers [17] (Salles and Matin, unpublished).

7. Directed evolution of YieF. We thus conducted directed evolution of the YieF enzyme to improve its efficiency for chromate reduction followed by high throughput screening [17, 18]. Y6 enzyme is the most effective isolated by this method with a 30 -fold greater $\mathrm{V}_{\max }$ for chromate reduction than YieF as well as other improved characteristics (Table 1). Later studies showed that the evolved enzyme was markedly active also in uranyl reduction (Table 2). We have also used a colorimetric method for a direct high throughput screening of genes encoding improved uranyl reductase activity. Although several have been found, none so far encodes a protein more active in this respect than Y128 and $\mathrm{Y} 150$ [18].

\begin{tabular}{lllll}
\hline \multicolumn{5}{c}{ Table 1. Kinetics of Cr(VI) reduction of the wild type YieF and the evolved enzymes. } \\
\hline Strain & $\mathbf{V}_{\mathbf{m a x}}\left(\mathbf{n m o l} \mathbf{C r}(\mathbf{V I}) \mathbf{m g}\right.$ protein $\left.{ }^{-1} \mathbf{m i n}^{-1}\right)$ & $\mathbf{K}_{\mathbf{m}}(\boldsymbol{\mu M})$ & $\mathbf{K}_{\text {cat }}{ }^{*}\left(\mathbf{S}^{-1}\right)$ & $\mathbf{K}_{\text {cat }} / \mathbf{K}_{\mathbf{m}}$ \\
\hline YieF & $295 \pm 27$ & $376 \pm 14$ & $30 \pm 2$ & $4.5 \times 10^{4} \pm 3 \times 10^{3}$ \\
Y6 & $8,812 \pm 611$ & $41 \pm 5$ & $521 \pm 18$ & $1.3 \times 10^{7} \pm 3 \times 10^{5}$ \\
Y150 & $258,333 \pm 16,875$ & $881 \pm 353$ & $57,445 \pm 3,321$ & $3 \times 10^{7} \pm 1 \times 10^{6}$ \\
\hline
\end{tabular}

\begin{tabular}{l} 
8. \\
approach to further YieF \\
\hline evolution. In collaboration \\
with Dr. Yuval Nov (New \\
York and Haifa
\end{tabular}

Universities), we have also combined directed evolution approach with rational methods of enzyme improvement. Dr. Nov while at Stanford in Dr. Wein's group [19] developed a system for optimizing protein activity under resource constraint, and devised a method to predict improved protein activity based on a limited number of protein variants. Applying his stochastic model relating the sequence and activity of a protein to the 16 mutants of the YieF enzyme involving mutations at 11 positions in the protein and Maximum Likelihood Analysis implemented through MATLAB's optimization toolbox, the 5 two-point mutants with the highest predicted activity were

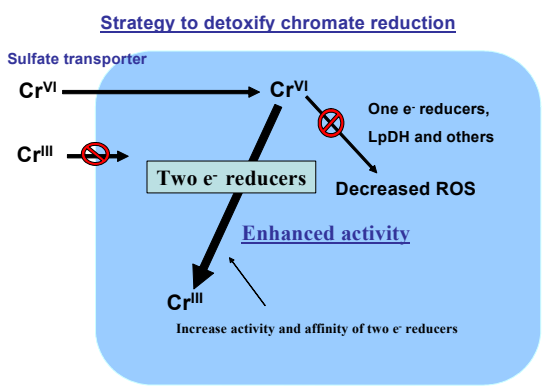

Figure 3. Strategy to minimize chromate toxicity to bacteria - circumventing chromate channeling to one-electron reducers. identified and selected to be expressed and screened. All 5 exhibited enhanced activity - on average, higher than the already high average activity of the 16 sequences in the initial data set $(p<$ 0.01 ). One of the five mutants, Y150, showed $>830$-fold improvement in activity over the wild type with respect to chromate reductase activity, making it the most active chromate reductase known (Tables 1 \& 2; Barak, Y., Nov, Y., Matin, A. In preparation). This is the enzyme is the main focus of ongoing studies.

9. Evolved enzymes and cancer chemotherapy. Based on the general characteristics of YieF, Y6, and Y150, we tested the latter for prodrug reduction activity and found that they were highly effective in reducing disparate prodrugs, such as mitomycin $\mathrm{C}$, 5-aziridinyl-2,4-dinitrobenzamide (CB 1954) and the drug 17-Allylamino-17-demethoxygeldanamycin (17-AAG) [18] (Barak, Y., Matin, A., unpublished). These prodrugs become activated upon reduction and are a highly promising approach to cancer chemotherapy, and thus a side-benefit of this research has been a potentially greatly improved prodrug therapy [18]. 
10. Amino acid changes underlying improved activity. Y6 exhibited four substitutions, however, reversion studies showed that only one change $\mathrm{Tyr}^{128}$ to Asn was responsible for its improved activity.

\begin{tabular}{|c|c|c|c|c|}
\hline $\begin{array}{l}\text { Strai } \\
\text { n }\end{array}$ & $\mathrm{V}_{\max }\left(\mathrm{nmol} \mathrm{U}(\mathrm{VI}) \mathrm{mg}\right.$ protein $\left.{ }^{-1} \min ^{-1}\right)$ & $\mathbf{K}_{\mathrm{m}}(\boldsymbol{\mu M})$ & $\mathbf{K}_{\mathrm{cat}} *\left(\mathbf{S}^{-1}\right)$ & $\mathbf{K}_{\mathrm{cat}} / \mathbf{K}_{\mathrm{m}}$ \\
\hline YieF & $213 \pm 17$ & $108 \pm 49$ & $29 \pm 11$ & $1.6 \times 10^{4} \pm 1.7 \times 10^{3}$ \\
\hline Y6 & $2,511 \pm 421$ & $779 \pm 40$ & $331 \pm 39$ & $5 \times 10^{5} \pm 2 \times 10^{4}$ \\
\hline Y150 & $4,814 \pm 462$ & $221 \pm 54$ & $333 \pm 37$ & $7 \times 10^{5} \pm 7 \times 10^{4}$ \\
\hline
\end{tabular}
Y150 has an additional substitution, Gly ${ }^{150}$ Ser. That relatively minor changes in the parent enzyme led to marked increases in activity for reducing disparate electrophiles suggests that the amino acid change(s) resulted in amplification of the original enzyme properties, including its broad substrate range, reinforcing the choice of YieF for these studies. They also provide the rationale for the hypothesis we would like to pursue that Y150 is likely to be more active also in reducing other radionuclides. Using the redox balance method and, in collaboration with the Francis group using XANES, we showed that the modification in the enzyme did not alter its characteristic for $\mathrm{Cr}$ (III) generation by a simultaneous four-electron chromate reduction $[17,18]$.

11. Envelope permeability-imposed limitation. We tested the efficacy of Y6 for chromate and uranyl reduction in P. putida. The broad host range vector pMMB67EH was used to introduce the YieFor Y6- encoding genes (yieF and $y 6$, respectively) into Pseudomonas (CRK4 strain). Bacteria over-
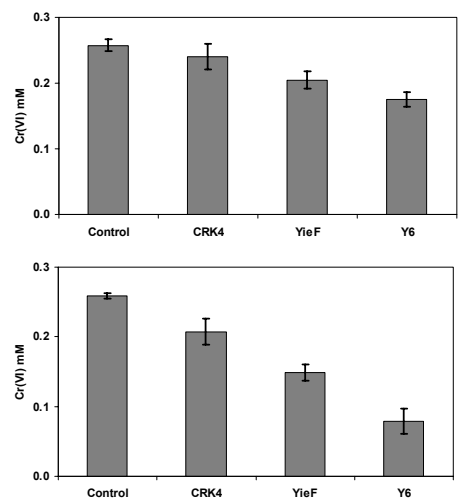

Figure 4. A (upper panle). Cr(VI) conversion by whole cells of $P$. putida, transformed with the empty plasmid, or plasmid containing the yieF or y6 gene. 'Control' refers to chromate conversion in LB medium alone. B (lower panel). Chromate conversion by crude extracts of the above strains. expressing YieF- or $\mathrm{Y} 6$ exhibited only marginally improved chromate reductase activity (Fig. 4A). However, cell extracts of the yieFtransformed strain showed higher and those of $y 6$-transformed strain even higher chromate reductase activity than the CRK4 extracts (Fig. 4B). The results indicate that the E. coli genes yieF and its evolved versions were expressed in $P$. putida and suggest that the permeability barrier to chromate masked the enhanced cellular chromate reductase activity of the transformed strains. To further test the involvement of the transport barrier, the capacity of the transformed cells to reduce chromate was determined following their permeabilization by chloroform treatment. The recombinant strains expressing YieF and Y6 now showed greater reductase activity than the non-transformed strain, with the Y6-expressing strain showing the highest activity (Fig 5).

When the E. coli mutant NR698 which is impaired in outer membrane permeability [20] was transformed with these plasmids, the advantage of Y6 in whole cell reduction of chromate again became evident: the mutant expressing this enzyme reduced chromate at a faster rate than the wild type expressing the enzyme. Chloroform-treated MC4100 and NR698 (nonexpressing or overexpressing the cloned YieF or Y6) exhibited a greater reduction rate than untreated NR698 strain, but the difference was only 10-20\%. Thus, while cytoplasmic membrane transport barrier also contributed to the masking of Y150 activity, the main barrier was the outer membrane impermeability.

12. Uranyl reduction. Similar results were obtained with uranyl indicating the need to improve envelope permeability to take full advantage of the improved enzyme in enhancing bacterial capacity for uranyl reduction as well. Appropriate controls indicated that uranyl disappearance was not due to trivial reasons such as binding to medium constituents or to the cells [17]. Why was the reduced U not oxidized back to uranyl under the aerobic conditions used is not known. Whether sequestration of $U(I V)$ within the cell and/or complexation with the medium are possibilities that are being investigated.

13. Physiological role of bacterial obligate two-electron reducing oxidoreductases. All of these enzymes also reduced quinones with high efficiency. Just as with chromate, many bacterial enzymes can vicariously reduce quinones by one electron reduction. This generates semiquinone which, like $\mathrm{Cr}(\mathrm{V})$, is subject to redox cycling, ROS and oxidative stress generation. Quinones are a constant potential threat to bacteria, being produced by cellular metabolism of aromatics and excreted by plants for defense against 
bacterial infections. All three obligate two-electron reducers we examined, YieF, ChrR, and NfsA, were able to outcompete one electron quinone reducers. Absence of $\mathrm{ChrR}$ and its overproduction made the cells less and more resistant, respectively, to $\mathrm{H}_{2} \mathrm{O}_{2}$ than the wild type.

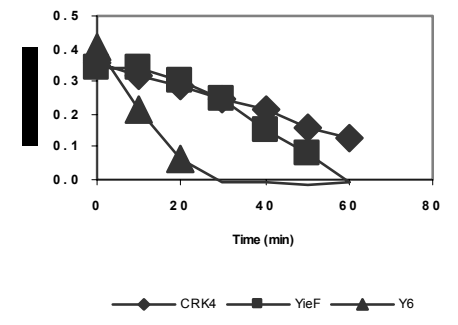

Figure 5. $\mathrm{Cr}(\mathrm{VI})$ conversion by whole cells of chloroform-permeabilized $P$. putida, transformed with the empty plasmid $(\bullet)$, or plasmid containing the $y i e F(\boldsymbol{\square})$ or $y 6(\mathbf{\Delta})$ gene. The experiment was conducted in triplicate runs. Variations between the mean values of each run were less than $10 \%$ as determined by the analysis of co-variance. Fluorescent-activated cell sorting confirmed that the loss or overproduction of $\mathrm{ChrR}$ inside the cell correlates with intracellular levels of $\mathrm{H}_{2} \mathrm{O}_{2}$. Protein carbonylation, which reflects intracellular oxidative stress, corroborated these results. Thus, the obligate twoelectron bacterial oxidoreductases are designed to counter oxidative stress. Evidently, because of their broad substrate range, they can be recruited to minimize oxidative stress from compounds, such as chromate and quinones that have proclivity for one electron reduction [21].

These findings reinforce two of the premises and objectives of this research, namely that strengthening the activity of these enzymes in the cells will make them more robust and efficient in stressful environments such as the DOE waste sites; and two, that they and their improved variants may be active in also reducing other metals and radionuclides to their stable reduced forms, since many of the latter also are likely to be subject to one-electron reduction.

We have thus attained to a large degree the aim of the research namely evolving highly efficient enzymes that can enhance the capacity of bacteria for remediating multiple metal and radionuclide DOE contaminants while minimizing their toxicity to the bacteria. The stage is now set to explore the possibilities offered by these findings to extend the promise of Y150 type enzymes to: (a) encompass also reduction of additional DOE metals and radionuclides; (b) test the effectiveness of bacteria expressing Y150 to remediate metal and radionuclides in settings that resemble DOE site conditions; and (c) to determine their selective advantage and ecological impact in such settings.

\section{LITERATURE CITED}

1. Keyhan MA, D.F.; Matin, A.: Targets of improvement in bacterial chromate bioremediation. In: Second International Conference on Remediation od Contaminated Sediments: 2003; Venice, Italy: Battelle Press; 2003: 1-8.

2. Ackerley DF, Barak Y, Lynch SV, Curtin J, Matin A: Effect of chromate stress on Escherichia coli K-12. J Bacteriol 2006, 188(9):3371-3381.

3. Hu P, Brodie EL, Suzuki Y, McAdams HH, Andersen GL: Whole-genome transcriptional analysis of heavy metal stresses in Caulobacter crescentus. $J$ Bacteriol 2005, 187(24):8437-8449.

4. Ishibashi Y, Cervantes C, Silver S: Chromium reduction in Pseudomonas putida. Appl Environ Microbiol 1990, 56(7):2268-2270.

5. Wade R, DiChristina TJ: Isolation of U(VI) reduction-deficient mutants of Shewanella putrefaciens. FEMS Microbiol Lett 2000, 184(2):143-148.

6. $\quad$ Liu C, Gorby YA, Zachara JM, Fredrickson JK, Brown CF: Reduction kinetics of $\mathrm{Fe}(\mathrm{III}), \mathrm{Co}(\mathrm{III}), \mathrm{U}(\mathrm{VI}), \mathrm{Cr}(\mathrm{VI})$, and Tc(VII) in cultures of dissimilatory metalreducing bacteria. Biotechnol Bioeng 2002, 80(6):637-649.

7. Shi XL, Dalal NS: NADPH-dependent flavoenzymes catalyze one electron reduction of metal ions and molecular oxygen and generate hydroxyl radicals. FEBS Lett 1990, 276(1-2):189-191. 
8. Ackerley DF, Gonzalez CF, Park CH, Blake R, 2nd, Keyhan M, Matin A: Chromatereducing properties of soluble flavoproteins from Pseudomonas putida and Escherichia coli. Appl Environ Microbiol 2004, 70(2):873-882.

9. Ackerley DF, Gonzalez CF, Keyhan M, Blake R, 2nd, Matin A: Mechanism of chromate reduction by the Escherichia coli protein, $\mathrm{Nfs} A$, and the role of different chromate reductases in minimizing oxidative stress during chromate reduction. Environ Microbiol 2004, 6(8):851-860.

10. Drapeau GR, Gariepy F, Boule M: Regulation and SOS induction of division inhibition in Escherichia coli K12. Mol Gen Genet 1984, 193(3):453-458.

11. Niederhoffer EC, Naranjo CM, Bradley KL, Fee JA: Control of Escherichia coli superoxide dismutase (sod $A$ and sodB) genes by the ferric uptake regulation (fur) locus. J Bacteriol 1990, 172(4):1930-1938.

12. Pinto R, Tang QX, Britton WJ, Leyh TS, Triccas JA: The Mycobacterium tuberculosis cysD and cysNC genes form a stress-induced operon that encodes a tri-functional sulfate-activating complex. Microbiology 2004, 150(Pt 6):1681-1686.

13. Singh J, Carlisle DL, Pritchard DE, Patierno SR: Chromium-induced genotoxicity and apoptosis: relationship to chromium carcinogenesis (review). Oncol Rep 1998, 5(6):1307-1318.

14. Park CH, Keyhan M, Wielinga B, Fendorf S, Matin A: Purification to homogeneity and characterization of a novel Pseudomonas putida chromate reductase. Appl Environ Microbiol 2000, 66(5):1788-1795.

15. Park CH, Gonzalez CF, Ackerley DF, Keyhan M, Matin A: Molecular engineering of soluble bacterial proteins with chromate reductase activity. In: First International Conference on Remediation of Chlorinated Sediments: 2002; Venice, Italy: Battelle Press; 2002: 103-111.

16. Zenno S, Koike H, Kumar AN, Jayaraman R, Tanokura M, Saigo K: Biochemical characterization of $\mathrm{NfsA}$, the Escherichia coli major nitroreductase exhibiting a high amino acid sequence homology to Frp, a Vibrio harveyi flavin oxidoreductase. $J$ Bacteriol 1996, 178(15):4508-4514.

17. Barak Y, Ackerley DF, Dodge CJ, Lal B, Cheng A, Francis AJ, Matin A: Analysis of novel soluble $\mathrm{Cr}(\mathrm{VI})$ and $\mathrm{U}(\mathrm{VI})$ reductases and generation of improved enzyme using directed evolution. Environmental Microbiology 2006, Submitted.

18. Barak Y, Thorne SH, Ackerley DF, Lynch SV, Contag CH, Matin A: New enzyme for reductive cancer chemotherapy, YieF, and its improvement by directed evolution. Mol Cancer Ther 2006, 5(1):97-103.

19. Nov Y, Wein LM: Modeling and analysis of protein design under resource constraints. J Comput Biol 2005, 12(2):247-282.

20. Ruiz N, Kahne D, Silhavy TJ: Advances in understanding bacterial outer-membrane biogenesis. Nat Rev Microbiol 2006, 4(1):57-66.

21. Gonzalez CF, Ackerley DF, Lynch SV, Matin A: ChrR, a soluble quinone reductase of Pseudomonas putida that defends against H2O2. J Biol Chem 2005, 280(24):2259022595.

22. Matin A: Isolation of high substrate affinity bacteria from Yucca Mountain sediment, using a chemostast. In: Report of completed research to Lawrence Livermore laboratory, Berkeley, CA. Berkeley, CA; 1995. 
23. Pandza S, Baetens M, Park CH, Au T, Keyhan M, Matin A: The G-protein FlhF has a role in polar flagellar placement and general stress response induction in Pseudomonas putida. Mol Microbiol 2000, 36(2):414-423.

24. Matin A, Little CD, Fraley CD, Keyhan M: Use of Starvation Promoters To Limit Growth and Selectively Enrich Expression of Trichloroethylene- and PhenolTransforming Activity in Recombinant Escherichia coli. Appl Environ Microbiol 1995, 61(11):4140.

\section{PUBLICATIONS AND PRESENTATIONS RESULTING IN THE CURRENT GRANT PERIOD $(09 / 15 / 2003-06 / 15 / 2006$}

\section{Journal articles}

1. Ackerley, D.F., C.F. Gonzalez, C.H. Park, R. Blake II, M. Keyhan, and A. Matin. 2004. Chromate reducing properties of soluble flavoproteins from Pseudomonas putida and Escherichia coli. Applied \& Environmental Microbiology 70: 873-882

2. Ackerley, D.F., C.F. Gonzalez, C.H. Park, R. Blake II, M. Keyhan, and A. Matin. 2004. Mechanism of chromate reduction by the Escherichia coli protein, NfsA, and the role of different chromate reductases in minimizing oxidative stress during chromate reduction. Environmental Microbiology, 6 (8): 851-860

3. Gonzalez, C.F., D.F. Ackerley, S.V. Lynch, and A. Matin. 2005. ChrR, a soluble quinone reductase of Pseudomonas putida that defends against $\mathrm{H}_{2} \mathrm{O}_{2}$. The Journal of Biological Chemistry. 280(24): 22590-22595.

4. Yoram Barak, Stephen H. Thorne, David F. Ackerley, Susan V. Lynch, Christopher H. Contag, and A. Matin. 2006. New enzyme for reductive cancer chemotherapy (YieF) and its improvement by directed evolution. Molecular Cancer Therapeutics 5(1): 97-103.

5. Ackerley, D.F., Y. Barak, S.V. Lynch, J. Curtin, and A. Matin. 2006. Effect of chromate stress on Escherichia coli K12. Journal of Bacteriology 188 (9): 3371-3381

6. Barak, Y., D. F. Ackerley, C. J. Dodge, L. Banwari, C. Alex, A. J. Francis, and A. Matin ${ }^{1}$.Analysis of novel soluble chromate and uranyl reductases and generation of an improved enzyme using directed evolution. Submitted, Nature Biotechnology

7. Nov, Y., Y. Barak, and A. Matin. A stochastic model assisted directed evolution of an enzyme with high activity for reducing chromate, uranyl and several prodrugs. About to be submitted.

\section{Conference Proceedings}

8. M. Keyhan, D. F. Ackerley, and A. Matin. 2003. Targets of improvement in bacterial chromate bioremediation. In Remediation of Contaminated Sediments-2003. Proceedings of the Second International Conference on Remediation of Contaminated Sediments (Venice, Italy; $30 \mathrm{Sep}-3$ Oct 2003), M. Pellei and A. Porta (Eds.), Battelle Press, Columbus, OH, Paper, E-06. ISBN 157477-143-4 
9. Matin, A. 2003. The bacterial general stress response. Desk Encyclopedia of Microbiology, Moshe Schaecter, editor. John Wiley. Pp. 167-190

10, Matin, A. 2004. Molecular approaches to improve bacterial bioremediation capacity with special reference to chromate bioremediation. In Proceedings of International Symposium of Environmental Biotechnology on Bioenergy and Bioremdiation, Organized by National Cheng Kung University, Taiwan, ROC 21 COE GREEN ENERGY, Nagoaka University of Technology, Japan.

11. David F Ackerley, Claudio F Gonzalez, Mimi Keyhan, Robert Blake III, and A Matin. 2005. Biomolecular strategy to decrease chromate toxicity to remediating bacteria. Water Resources Management III, de Conceicao Cunha, M., and Brebbia, C.A., editors, WIT press (www.witpress.com), pp. 259-267

12. Gonzalez' C., D. Ackerley, M. Keyhan, R. Blake II, and A. Matin. 2005. Evaluation of class II chromate reductases and their bioremediation potential. Paper C6-09, in: R.F. Olfenbuttel and P.J. White (Eds.), Remediation of Contaminated Sediments-2005: $\quad$ Finding Achievable Risk Reduction Solutions. Proceedings of the Third International Conference on Remediation of Contaminated Sediments (New Orleans, Louisiana; Jan 24-27, 2005). ISBN 1-57477-150-7, published by Battelle Press, Columbus, $\mathrm{OH}$, www.battelle.org/bookstore.

\section{Popular press}

13. The Big Idea: Accelerated Bioremediation: Genetically engineering bacteria to eat our most toxic Superfund sites for dinner. By Katharine Mieszkowski. Salon.com, on-line news and current events magazine, October 212005. http://www.salon.com/mwt/feature/2005/10/21/big_idea_enviro/print.html

Patents

14. Matin, A., Y. Barak, S. Lynch, and D. Ackerley. Improved enzymes for reductive prodrug cancer chemotherapy. S05-276.

15. Matin, A., Y. Barak, S. Thorne, C. Contag, and J. Rao. A novel prodrug for reductive cancer chemotherapy that can be visualized in vivo and can be used in high throughput screening assay for the development of improved nitro-reductase proteins for prodrug activation in vivo. Pending

\section{Abstracts of oral or poster presentations}

16. Gonzalez, C., D. Ackerley, M. Keyhan, R. Blake II, and A. Matin. 2003. Molecular biology and biology of bacterial chromate reduction. Abstracts of the $102^{\text {nd }}$ General meeting of the American Society for Microbiology, Washington D.C. , May 18-22, 2003, O-123

17. Gonzalez, C., D. Ackerley, M. Keyhan, R. Blake II, and A. Matin. 2003. Molecular biology and biology of bacterial chromate reduction. DOE NABIR P.I. Workshop. Warrenton, Va. P.40

18. Ackerley, D., C. Gonzalez, M. Keyhan, and A. Matin. 2004. Role of bacterial "chromate" reductases in antioxidant defense in bacteria. $103^{\text {rd }}$ General meeting of the American Society for Microbiology, Washington D.C. , May 2004 
19. Ackerley,D., C. Gonzalez, M. Keyhan, R. Blake II, and A. Matin. 2004. Biomolecular strategy to decrease chromate toxicity to remediating bacteria, Abstract \#93, Joint ACS $59^{\text {th }}$ Rocky Mountain Regional Meeting, June 6-9, 2004, Logan, Utah.

20. Ackerley,D., C. Gonzalez, M. Keyhan, R. Blake II, and A. Matin. 2004. Biomolecular strategy to decrease chromate toxicity to remediating bacteria, DOE NABIR P.I. Workshop, Warrenton, Va. P.43

21. Ackerley,D., C. Gonzalez, M. Keyhan, S. Gandler, R. Blake II, and A. Matin. 2005. Engineering bacteria for superior chromate bioremediation. Third international conference on remediation, New Orleans, January 24 to 30, 2005

22. Ackerley,D., Y. Barak, M. Keyhan, R. Blake II, and A. Matin. 2005. Superiority of obligate twoelectron reducers in bacterial chromate bioremediation DOE NABIR P.I. Workshop, Warrenton, Va.

23. Ackerley,D., C. Gonzalez, M. Keyhan, S. Gandler, R. Blake II, and A. Matin. 2005.

Biomolecular strategy to decrease chromate toxicity to remediating Bacteria. Third international conference one water resources management, 11 to 30 April 2005, Algrave, Portugal.

24. Ackerley,D., and A. Matin. 2004. Chromate-reducing flavoenzymes that guard against oxidative stress. West Coast Bacterial Physiologist Meeting, Asilomar, California

25. Ackerley, D, C. Gonzalez, S. Lynch, and A. Matin. 2005. ChrR is a chromate reducing flavoprotein of Pseudomonas putida that also defends against oxidative stress in vivo. Abstracts of the $105^{\text {th }}$ General Meeting of American Soc. for Microbiology, Atlanta, GA, June 5-9, 2005, Abstract no. K-094.

26. Barak, Y., S. Thorne, D. Ackerley, S. Lynch, C. Contag, and A. Matin. Improved enzymes, generated by DNA shuffling, for reductive cancer chemotherapy. To be presented at AACR-NCI-EORTC International Conference on Molecular Targets and Cancer Therapeutics. November 14-18, 2005, Philadelphia, PA

27. Francis, A.J., and A.C. Matin. 2006. Molecular mechanisms of uranium reduction by Clostridia and its manipulation, DOE NABIR P.I. Workshop, Warrenton, Va. P.50

28. Barak, Y., D. Ackerley, C. Dodge, A. Cheng, Y. Nov, A. Francis, and A. C. Matin. 2006. Generation of a novel high-activity enzyme with combined $\mathrm{Cr}(\mathrm{VI})$ and $\mathrm{U}(\mathrm{VI})$ reductase activities using directed evolution and rational design. DOE NABIR P.I. Workshop, Warrenton, Va. P.43

29. Yoram Barak, Stephen H. Thorne, Yuval Nov, Christopher H. Contag, Jianghong Rao, and A. Matin. 2006 Improved prodrug chemotherapy through directed enzyme evolution and discovery of a new prodrug. In press, International Journal of Oncology

\section{Other presentations}

30. Keynote speaker, "Molecular approaches to improve bacterial bioremediation capacity with special reference to chromate bioremediation", International Symposium of Environemental Biotechnologies on Bioenergy and Bioremediation. National Cheng Kung University, Tainan, Taiwan, September, 2004 (Two additional talks at affiliated Institutes on other aspects of molecular bioremediation) 
31. Plenary talk (by A.C. Matin), "Enzyme design for $\mathrm{Cr}(\mathrm{VI})$ and $\mathrm{U}(\mathrm{VI})$ reduction", NABIR meeting at Airlie Center, 2006. 